Available online: https://journals.researchsynergypress.com/index.php/ijebce/

International Journal of Entrepreneurship, Business and Creative Economy (IJEBCE)

ISSN 2775-3085 (Online) | 2775-3107 (Print)

Volume 1 Number 1 (2021): 25-38

\title{
The Determinants Factors of Womenpreneurship Performances in Low Economic Class: An Evidence from Melaka
}

\author{
Iylia Syafiqah Binti Abdul Malik', Vincent Chan ${ }^{1}$, Cheryl Chan ${ }^{1}$ \\ ${ }^{1}$ Faculty of Business, Multimedia University, Melaka, Malaysia
}

\begin{abstract}
Within this study, we want to examine factors those determine to the rise of womenpreneurship, since it is one of the most important 2030 Agenda for Sustainable Development to eradicate national poverty as well as to support the innovation and ever-growing economy. The increasing of women's participation in entrepreneurs demonstrated positive impact of female entrepreneurs, not only on the family but also on economic growth and development. We build our theoretical framework based on literature surveys; that factors of an inspiring role model, education on digital skills, and financial support, which taken from Theory of Planned Behaviour (TPB), contribute to this increasing of womenpreneurship participation. As far as we have known, we are among the first who establish the study focused on women entrepreneurs, especially among the B40 economic social class. We employ a quantitative approach of Multiple Regression Linear Analysis with a convenience sample, comprising 100 women entrepreneurs in Melaka. We find that women entrepreneurs with clear targets, would not only possess the right attitude in their entrepreneurial path, but also become the society role models at the same time. Also, when facing the social pressure, womenpreneurs will equip themselves with proper education to grasp more opportunities. Even though limited by the participation rate, especially those in the rural areas, we would like to make recommendations on ways to encourage more women to pursue entrepreneurship, especially during the Covid-19 outbreak.
\end{abstract}

Keywords: womenpreneurship; entrepreneurship; B40

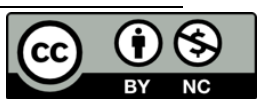

This is an open access article under the CC-BY-NC license.

\section{INTRODUCTION}

Even though in the old days, women were known as having the role of a housewife, which focused on their husband, children, and household work (Yusuff, Bakar \& Ahmad, 2016), in this era, women have advanced themselves, some of them choose the entrepreneurs way, and currently with the proliferation of social media platform, instantly they become. Entrepreneurship has been recognized as the new strategy for women to be part of the ever-growing entrepreneurship population (Ladge, Eddleston \& Sugiyama, 2019). Ladge et al. (2019) also mentioned that womenpreneurs could build a good rapport with potential customers and investors as they are more trustworthy. Women who were involved in entrepreneurial activities were said to become one of the solutions to the economic crisis (Bouzekraoui \& Ferhane, 2017) Bouzekraoui et al. (2017) have also stated thatwomen who carried out businesses created business opportunities, build networks, and expedite the access to finance.

Individuals who are in the income per month category of RM3,860 and below were recognized as the B40 group. Within our study, these women were the main focus of the rise in 
International Journal of Entrepreneurship, Business and Creative Economy (IJEBCE), Vol. 1 (1), 25-38 Womenpreneurship Performances in Low Economic Class : An Evidence from Melaka Iylia Syafiqah Binti Abdul Malik, Vincent Chan, Cheryl Chan

entrepreneurial participation, since our experiences showed that several B40 successful womenpreneur are the significant contributions to the country's economy. This encouraged and triggered many more women to become entrepreneurs, they believe that by creating new business, they will be able to generate income which, later on, to reduce poverty. Due to the overwhelming demand of women who wants to become entrepreneurs, the Malaysian government initiated a few programs and provided financial aid, especially for the B40 group. This policy, hence, will rise the womenpreneurship participation among the B40 group.

\section{Problems in the Rise of Womenpreneurship Among B40}

The role of women is the first central issues in our womenpreneurship studies, because their roles in social and economic development, specifically in the micro, socioeconomic development, and small scale enterprises, were vital for economic development in their communities (Nneka, 2015). In the study of Holienka, Jancovicova, and Kovacicova (2016), one of women role is to unveiled the untapped economic growth resources. Beside the roles, wealth creation and job generation are next to discuss, since the increasing of womenpreneur numbers will decrease the poverty level (Trang et al., 2019). Later on, the competitiveness in the knowledge-based global market is our third key to understand womenpreneurship, since the competitive entrepreneurship has been generally viewed as a method of promoting economic growth, creativity, and innovation (Gabriela Boldureanu et al., 2020), which all of them are an important entrepreneurial intention to sustain the business. Thus, based on abovementioned motivations, we want to study the determinant factors contributing to the rise of womenpreneurship among the B40 group in Melaka, inspired by the Theory of Planned Behaviour, as we want to encourage womenpreneurs to move forward.

We formulate our Research Objectives:

1. To identify the significant factors contributing to the rise of womenpreneurship among the B40 group.

2. To assess the growth of womenpreneurship by specifically reviewing literature reviews published from 2015 till 2020.

Our Research Questions are:

1. What are the factors contributing to the rise of womenpreneurship among B40 in Melaka?

2. What are the impacts of womenpreneurship on economic growth?

\section{LITERATURE REVIEW}

Over the past four decades, the women's population venturing into business and entrepreneurship has grown drastically (Kamaruddin, Arshad, Osman \& Buyong, 2018). Saidi, Rashid, Zin, Ramlan, Johari, and Mohamad (2017) discussed that womenpreneur were successful because of their internal determinants; they show that it was the believe they need to conduct and organize entrepreneurial activities that bring great achievements. Zeb (2018) studied that the factors that influence the womenpreneurs performance must constantly adapt to the change in the business environment, especially the rapid evolution in technology.

Trang et al. (2019) discussed that when potential entrepreneurs observe successful entrepreneurs as their role models, they tend to be more confident and have better knowledge in 
International Journal of Entrepreneurship, Business and Creative Economy (IJEBCE), Vol. 1 (1), 25-38 Womenpreneurship Performances in Low Economic Class : An Evidence from Melaka Iylia Syafiqah Binti Abdul Malik, Vincent Chan, Cheryl Chan

starting a business. Meanwhile Batool and Ullah (2017) stated that if women were given opportunities to express their thoughts and feelings, they would be more confident and creative. This reflects that women will be a great and inspiring role model for the other potential entrepreneurs. Research by Haxhiu (2015) found that most women entrepreneurs started their businesses because of the desire to be self-employed. This projects that women have a sturdy attitude in determining the best way to perform well and, at the same time, set an exemplary role as an entrepreneur. Individuals who have entrepreneurial attitudes were seen to have a positive attitude towards becoming an entrepreneur as they were aware of the outcome, potential benefits, and challenges that they might face (Asikhia, Agbonna, Makinde, and Akinlabi, 2019). One of the success factors of womenpreneurs was to possess the reliable social networks to access the external knowledge about the entrepreneurial environment (Holienka et al., 2016). The motivation for women entrepreneurs is their family members, which reflects the cultural values of families (Batool and Ullah,2017). Boldureanu et al. (2020) stated that the entrepreneurial role enables a person not only to generate career alternatives, but also to motivate them to become entrepreneurs. These influences and the networks, thus, allow entrepreneurs to obtain information from family, friends, and governmental agencies (Mozumdar, 2018). Nowinski and Haddoud (2019) stated that individuals that have homogenous ethnicity network were able to inspire society to pursue new business. Bosma, Hessels, and Schutjens (2012) highlighted the entrepreneurial role model to demonstrate good examples in business, since they set examples, mission, and vision to be followed by others. Wyrwich, Stuetzer, and Sternberg (2016) supported the notion that successful entrepreneurs can motivate existing entrepreneurs and increase an individual's self-confidence. We can be concluded that the entrepreneurial role model has a significant positive effect on womenpreneurship performance.

According to Goldie (2016), in this digital transformation of the business industry, entrepreneurs need to realize the need for lifelong learning. They must have the readiness to learn digital skills and knowledge to compete, as strengthen in Honig and Martin (2014), which showed that the digital literacy enabled constructive social action. Digital skills, the ability to use the internet for relevant information about the business, to utilize social media as a marketing tool, and to seek new ways to scale or promote their business using digital platforms, is a growing need to achieve competitiveness and continuity for business growth. Using all these digital tools and technologies, women entrepreneurs are exposed to a wide range of information that can foster openness to a new way to solve problems. Hence, it is important to have sufficient digital skills for an entrepreneur, to troubleshoot, to browse the web, and applications, to complete tasks and to address problems (Ryan et al. 2020). Grand-Clement (2016) showed that the ability to learn the digital skills will help womenpreneurs capacity boasted. For example, in addition to using the traditional ways of fliers and SMS, womenpreneurs need to know how to utilize social media platforms like TikTok, Facebook, and Instagram to broaden customer.

The educational levels of women has played a positive driver for them to become a succesful entrepreneurs, as discussed in Mehta (2018), Bakar \& Ahmad (2016), and Fatima \& Muneer (2018), that women entrepreneurs who are highly educated can run their business more successfully. Higher education plays an important role also in preparing women for the entrepreneurship world. Studies by Berii (2019) did mention that the knowledge they gain from their higher education institute like e- commerce, marketing, innovation, economics, 
International Journal of Entrepreneurship, Business and Creative Economy (IJEBCE), Vol. 1 (1), 25-38 Womenpreneurship Performances in Low Economic Class : An Evidence from Melaka Iylia Syafiqah Binti Abdul Malik, Vincent Chan, Cheryl Chan

entrepreneurship, and many more subjects that are related will drive a positive economic empowerment and equip them better to be a successful entrepreneur. This statement is in line with a study by Al-kwifi et al. (2019) that having the right knowledge to start up a business is very important towards the success of women entrepreneurs.

Having an education in digital skills also means involving innovative technologies. In this era of advanced technology and innovation, small start-ups look towards having an entrepreneurial mindset to find new opportunities (Smith et al., 2016). Even though the womenpreneurs do not have the opportunity to further their studies in universities, they still can learn and obtain the skills if they have the entrepreneurial mindset. With an entrepreneurial mindset, they will put effort into finding ways and opportunities to gain the digital skills needed to grow their business.

Also, the utmost importants is that the availability of systemic to ease womenpreneur. In this context, the government should provide financial, marketing, and training assistance so that women can start the business (Padmavati, D., 2002). Getting government support ultimately has a significant impact on the performance of women entrepreneurs. Al-Kwifi et al. mention that government support will have a positive impact on the overall performance of the women entrepreneurs business. There are many more previous studies that mention the positive relationship between financial support and the performance of the womenpreneur. As an example, a study by Doris (2016); Bakar \& Ahmad (2016), George (2018), mentioned that the lack of support by the government in terms of accessing financial help will hamper the performance of the business. Mustapha and Subramaniam (2015) also said that the key obstacle of womenpreneurs in Malaysia were financial factors. Based on Doris, 2016; Bakar \& Ahmad, 2016; George, 2018, they did also mention that the lack of access to finance is the main reason that affects the performance of women entrepreneurs. Fatima \& Muneer, 2018; Zeb, Arooj; Jan, Shahid; Ihsan, Anjum; Shah, 2019, stated that reasonable levied tax imposed by the government could also have a positive impact on the performance of women entrepreneurs.

Fatima \& Muneer, 2018; Zeb, Arooj; Jan, Shahid; Ihsan, Anjum; Shah, 2019 says that government regulation can have a significant effect on women entrepreneur's performance. This might include regulation in the ease of gaining and accessing financial assistance. As a new start-up business, many womenpreneur find difficulty in getting a bank loan. This is because there is a nonexistence of a track record. Some banks might ask for bank balances and documents to show their credibility in paying back the loan. Referring to the interview done in Mazlina \& Punitha (2016) research, some respondents did mention that some banks only will give the loan after two years of the business establishment. The government can also provide financial support in terms of giving the B40 womenpreneurs access to business training for free or at a lower price. Kementerian Pembangunan Wanita (The Women Empowerment Ministry) had done this by conducting a boot camp program called Growth for Lower- Income Women (GLOW). This Bootcamp is open for all B40 women entrepreneurs to learn new skills or enhance their existing skills in digital marketing, networking skills, communication, and many more. This kind of Bootcamp normally will be very expensive for them to join, but with the government initiative conducting this free boot camp for them, it somehow eases their financial burden.

At the same time, business, programs, and training show a positive impact on the performance of women in their business (Khaleque, 2018). Government initiatives and programs should cater to the needs of womenpreneurs and measure the success of the effort done for them 
International Journal of Entrepreneurship, Business and Creative Economy (IJEBCE), Vol. 1 (1), 25-38 Womenpreneurship Performances in Low Economic Class : An Evidence from Melaka Iylia Syafiqah Binti Abdul Malik, Vincent Chan, Cheryl Chan

(Mutalib and Arshad, 2015). Financial support is even more important in this current economic recovery situation, where a huge number of small and medium enterprises are affected. The government has launch stimulus packages to damper their loss and help them to rise again. With the allocation of RM100 billion in the Second Economic Stimulus Package 2020 (ESP2) themed Prihatin Rakyat, it is hoped that this can spur the economy to go forward. When there are more chances to access financial aid or help, the performance of the women entrepreneurs will also increase. This is proven based on the study done by Al-Kwifi et al., 2019; Rajan et al., 2019; Khaleque, 2018; and Salah, 2018, whereby financial accessibility is an important element of the performance of women entrepreneurs. As we know that financial aid is important in boosting or even starting a business, and it is more important for a business to continue to do well. Therefore, it is very important to gain financial support, especially from the government. Some studies have been done on successful business owners in Poland, and they found that they primarily depend on their resources to fund their business operations (Leszczyński, 2016). This study is not relevant, as the B40 womenpreneurs will have difficulty in using their resources to start a business.

\section{Theory Planned Behavior}

Theory Planned Behavior was used to explain the individual's entrepreneurial intentions based on attitudes, subjective norms, and perceived behavioral control (Tuan, Ha, Thao, Anh, and Long, 2019). The attitude towards starting a business shows a sturdy attitude of an individual to reveal potential future entrepreneurial behavior (Zovko, Dulcic, and Bilic, 2020). Tuan et al. (2019) stated that subjective norms refer to social pressure from individuals around us, and behaviors could have been more appealing if they have more pressure or expectation. A study was done by Hong, Sha'ari, Zulkiffli, Aziz, and Ismail (2020) mentioned that perceived behavioral control was seen as an important trigger for entrepreneurial intention and capability to run a company.

In order to understand some type of human behavior, theory of planned behavior has become the most significant theories that have been applied in almost every relevant discipline. (Aurelio, Pierpaolo, Orlando and Gennaro, 2018).

Involving in an entrepreneurial activity is considered as a planned behavior. Because of that, entrepreneurs need to have access to opportunities and resources (role model, education and financial support) in order to grow and expand their business. The theory of planned behavior seen as very suitable to explain and predict entrepreneurial behavior (performance).

\section{The growth of womenpreneurship}

In the past decades, the role of women in entrepreneurship is very minimal. Womenpreneurs create incremental wealth in their own family's finances and can be considered to be a minor contribution to the country's economy (Satyajit, Priyanka, and P. K., 2017). According to Ayogu and Agu (2015), supporting small and medium enterprises (SMEs) and poverty alleviation was said to be the importance of womenpreneurship.

Subsequently, the impact of womenpreneurs is becoming increasingly important to economic growth. A study by Trang et al. (2019) stated that womenpreneurs are sources of job generation for young people. Indirectly, it will decrease the unemployment rate for Malaysia. Womenpreneurs is the nation's strategy in promoting economic growth, creativity and serve as agents of innovation (Gabriela Boldureanu et al., 2020). 
International Journal of Entrepreneurship, Business and Creative Economy (IJEBCE), Vol. 1 (1), 25-38

Womenpreneurship Performances in Low Economic Class : An Evidence from Melaka

Iylia Syafiqah Binti Abdul Malik, Vincent Chan, Cheryl Chan

National Entrepreneurship Policy 2030 (NEP 2030) was introduced by the sixth Prime Minister of Malaysia on 11 July 2019. NEP 2030 is the first policy document by the newly established Ministry of Entrepreneur Development (MED) in line with the functions of the Ministry to formulate policies for the development of an inclusive and competitive entrepreneurial community, particularly the SME sector, that is capable of competing in the global market as well as to spur the development of the B40 group and social entrepreneurs. The main objective of NEP 2030 is to empower the B40 group by inculcating a culture of entrepreneurship.

According to Deputy Prime Minister Datuk Seri Dr. Wan Azizah Wan Ismail in 2018, one way to achieve the main objective of NEP 2030 is to bring onboard new enterprises and entrepreneurs, especially women entrepreneurs among the B40 group. Thus, the contribution of womenpreneurs is very important to Malaysia. Regardless of gender issues, the role of womenpreneurs turns out to be great.

\section{RESEARCH METHOD}

This study investigates factors contributing to the rise of womenpreneurship among B40. This section of the chapter presents the response rate of the targeted population, namely the women entrepreneurs in Malacca. Out of the 150 questionnaires distributed to the women entrepreneurs via the online platform, 143 (95.33\%) were returned. The return rate was above $80 \%$ and therefore considered sufficient for data analysis.

The researcher will use the exploratory research design. Exploratory research type design is used by conducting online questionnaires. The questionnaire includes two sections whereby Section A is for demographic and Section B is for the dependent variable (DV), and independent variables (IV). For Section B, researcher run two analysis which are Reliability Analysis and Multiple Linear Regression analysis for this research, which is womenpreneurship performance (DV), inspiring role model (IV1), education in digital skills (IV2) and financial support (IV3). For section $B$, seven questions for each element, and the respondent answers on a Likert scale.

\section{Sampling design}

Convenience Sampling was used for the study since it includes womenpreneurs among B40 economic class, who were reachable during pandemic COVID 19 (state period of sampling).

\section{Statistical analysis tools}

The data has been analysed by SPSS and will be tested using Reliability Analysis and Multiple Regression Linear Analysis.

\section{The Research Framework}

H01: There is no significant relationship between inspiring role model and womenpreneurship performance.

Ha1: There is a significant relationship between inspiring role model and womenpreneurship performance.

H02: There is no significant relationship between digital education and womenpreneurship performance. 
International Journal of Entrepreneurship, Business and Creative Economy (IJEBCE), Vol. 1 (1), 25-38 Womenpreneurship Performances in Low Economic Class : An Evidence from Melaka Iylia Syafiqah Binti Abdul Malik, Vincent Chan, Cheryl Chan

Ha2: There is a significant relationship between digital education and womenpreneurship performance.

H03: There is no significant relationship between financial support and womenpreneurship performance.

Ha3: There is a significant performance relationship between financial support and womenpreneurship

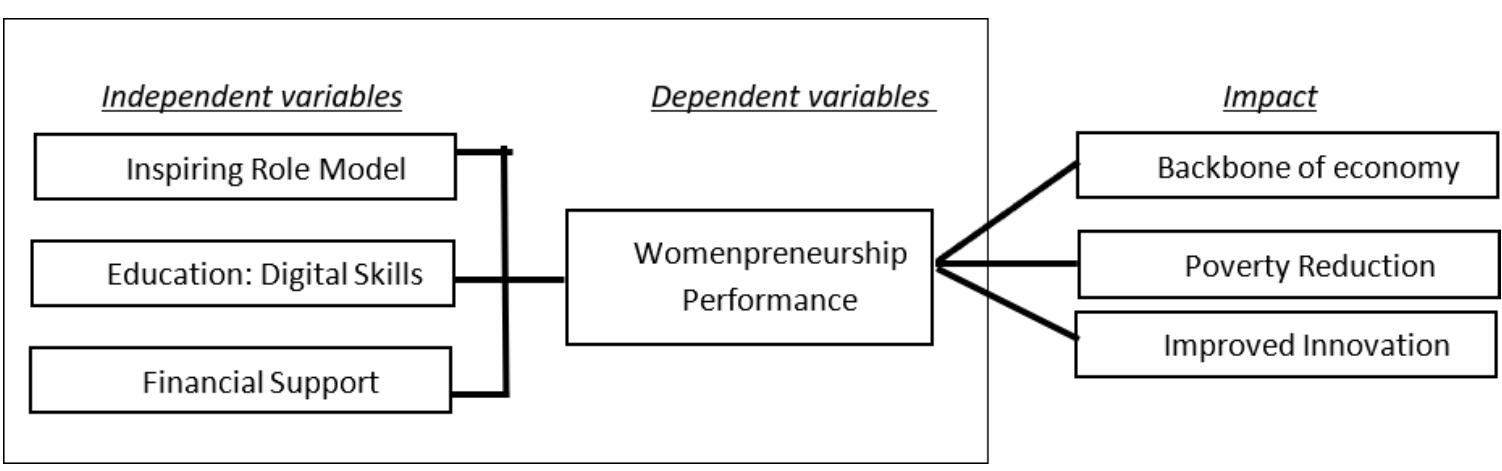

Figure 1: The framework of Determinants contributing to the rise of womenpreneurship among B40.

\section{FINDINGS AND DISCUSSION}

Demographic Analysis

Table 1: Demographic Analysis

\begin{tabular}{lll}
\hline Respondents & 143 & \\
Gender & Female & $100 \%$ \\
\hline \multirow{2}{*}{ Age } & $20-25$ years old & $15.05 \%$ \\
& $26-30$ years old & $18.28 \%$ \\
& $31-35$ years old & $32.26 \%$ \\
& $35-40$ years old & $7.53 \%$ \\
& 40 years old and above & $26.88 \%$ \\
\hline \multirow{2}{*}{ Educational Background } & PMR & $6.45 \%$ \\
& SPM & $31.18 \%$ \\
& Diploma & $33.34 \%$ \\
& Degree & $20.43 \%$ \\
& Masters & $8.60 \%$ \\
\hline 31 & & \\
\hline
\end{tabular}


International Journal of Entrepreneurship, Business and Creative Economy (IJEBCE), Vol. 1 (1), 25-38 Womenpreneurship Performances in Low Economic Class : An Evidence from Melaka Iylia Syafiqah Binti Abdul Malik, Vincent Chan, Cheryl Chan

\begin{tabular}{|c|c|c|}
\hline & $\mathrm{PhD}$ & $0 \%$ \\
\hline \multirow[t]{4}{*}{ Ethnicity } & Malay & $77.42 \%$ \\
\hline & Chinese & $8.60 \%$ \\
\hline & Indian & $5.38 \%$ \\
\hline & Other & $8.6 \%$ \\
\hline \multirow[t]{4}{*}{ Current employment status } & Employed: Full time working & $56.99 \%$ \\
\hline & Employed: Part time working & $\begin{array}{l}5.38 \\
\%\end{array}$ \\
\hline & Self employed & $\begin{array}{l}24.7 \\
3 \%\end{array}$ \\
\hline & Housewife & $\begin{array}{l}12.9 \\
0 \%\end{array}$ \\
\hline \multirow[t]{3}{*}{ Income } & Below RM 2,000 & $\begin{array}{l}41.9 \\
4 \% \\
\end{array}$ \\
\hline & RM 2,001 - RM 3,000 & $\begin{array}{l}24.7 \\
3 \%\end{array}$ \\
\hline & RM 3,001 - RM 4,000 & $\begin{array}{l}33.3 \\
4 \% \\
\end{array}$ \\
\hline \multirow[t]{3}{*}{ Relationship status } & Married & $\begin{array}{l}73.1 \\
9 \%\end{array}$ \\
\hline & Single & $\begin{array}{l}23.6 \\
6 \%\end{array}$ \\
\hline & Divorced & $\begin{array}{l}3.23 \\
\%\end{array}$ \\
\hline \multirow[t]{4}{*}{ Numbers of children } & 0 & $\begin{array}{l}38.7 \\
1 \%\end{array}$ \\
\hline & 1-3 children & $\begin{array}{l}47.3 \\
1 \%\end{array}$ \\
\hline & 4-6 children & $\begin{array}{l}10.7 \\
5 \%\end{array}$ \\
\hline & 7 and above & $\begin{array}{l}3.23 \\
\%\end{array}$ \\
\hline
\end{tabular}

In your opinion, what are obstacles faced in a start-up business?

Competition

Lack of skills

Lack of resources

Lack of Experience

Lack of Opportunities

$9.68 \%$

Regulations

$0 \%$ 
International Journal of Entrepreneurship, Business and Creative Economy (IJEBCE), Vol. 1 (1), 25-38 Womenpreneurship Performances in Low Economic Class : An Evidence from Melaka Iylia Syafiqah Binti Abdul Malik, Vincent Chan, Cheryl Chan

Table 1 summarizes the demographic information of women entrepreneurs in the B40 category. The respondents to the questionnaire were only women, and SPSS 27 software was used for analyzing the data.

\section{Reliability Analysis}

Table 2: Reliability Analysis

\begin{tabular}{|c|c|c|}
\hline Variables & \multicolumn{2}{|c|}{$\begin{array}{l}\text { No. of items and } \\
\text { Cronbach's Alpha based on standardized item }\end{array}$} \\
\hline \multirow[t]{3}{*}{ Performance } & \multicolumn{2}{|c|}{ Reliability Statistics } \\
\hline & $\begin{array}{c}\text { Cronbach's } \\
\text { Alpha }\end{array}$ & $\mathrm{N}$ of Items \\
\hline & .946 & 7 \\
\hline \multirow[t]{3}{*}{ Role Model } & \multicolumn{2}{|c|}{ Reliability Statistics } \\
\hline & $\begin{array}{l}\text { Cronbach's } \\
\text { Alpha }\end{array}$ & $\mathrm{N}$ of Items \\
\hline & .941 & 7 \\
\hline \multirow[t]{3}{*}{ Education (Digital) } & \multicolumn{2}{|c|}{ Reliability Statistics } \\
\hline & $\begin{array}{c}\text { Cronbach's } \\
\text { Alpha }\end{array}$ & $\mathrm{N}$ of Items \\
\hline & .895 & 6 \\
\hline \multirow[t]{3}{*}{ Financial Support } & \multicolumn{2}{|c|}{ Reliability Statistics } \\
\hline & $\begin{array}{c}\text { Cronbach's } \\
\text { Alpha }\end{array}$ & $\mathrm{N}$ of Items \\
\hline & .730 & 5 \\
\hline
\end{tabular}

Table 2 shows the reliability of the questions used in the questionnaires that were distributed to women entrepreneurs via google form. The questionnaire consisted of items testing the dependent and independent variables which were divided into 5 different sections.

The dependent variable is women entrepreneurs performance and independent variables are role model, education in digital and financial support whereby the Crobach's Alpha result for women entrepreneurs performance (DV) and role model (IV 1) are 0.9 and above. 
International Journal of Entrepreneurship, Business and Creative Economy (IJEBCE), Vol. 1 (1), 25-38

Womenpreneurship Performances in Low Economic Class : An Evidence from Melaka Iylia Syafiqah Binti Abdul Malik, Vincent Chan, Cheryl Chan

Meanwhile, for education in digital (IV 2) and financial support (IV 3), the Crobach's Alpha result is in good and acceptable range. Therefore, the reliability result shows a high degree of internal consistency. Overall, the finalized data of this study is believed to be highly reliable for further statistical analysis. Cronbach's Alpha of all the variables is exceeding 0.7 and none of the item or question is deleted.

Multiple Linear Regression analysis

Table 3: Model Summary b

Model Summary

\begin{tabular}{ll|lll} 
Model & R & R Square & $\begin{array}{l}\text { Adjusted } \\
\text { Square }\end{array}$ & $\begin{array}{c}\text { RStd. Error of the } \\
\text { Estimate }\end{array}$ \\
\hline 1 & $.859^{\mathrm{a}}$ & .676 & .562 & .51942 \\
\hline
\end{tabular}

a. Predictors: (Constant), TF, TM, TE

b. Dependent Variable: TP

According to Table 3, the R Square value was 0.676 . It shows that $67.6 \%$ of the variance of womenpreneurship performance can be explained by the inspiring model, education in digital skills, and financial support. Meanwhile, another $32.4 \%$ of factors to womenpreneurship performance are obtained by other independent variables, which has not been measured in this study.

Table 4 : Coefficients a

\section{Coefficients}

\begin{tabular}{|c|c|c|c|c|c|c|}
\hline \multirow{2}{*}{\multicolumn{2}{|c|}{ Model }} & \multicolumn{2}{|c|}{ Unstandardized Coefficients } & \multirow{2}{*}{$\begin{array}{c}\text { Standardized } \\
\text { Coefficients } \\
\text { Beta }\end{array}$} & \multirow[b]{2}{*}{$\mathrm{t}$} & \multirow[b]{2}{*}{ Sig. } \\
\hline & & B & Std. Error & & & \\
\hline \multirow[t]{4}{*}{1} & (Constant) & 2.066 & .318 & & 3.444 & .001 \\
\hline & TM & .172 & .061 & .240 & 2.808 & .031 \\
\hline & TE & .717 & .120 & .675 & 5.974 & .000 \\
\hline & $\mathrm{TF}$ & 667 & .128 & .075 & -615 & .004 \\
\hline
\end{tabular}

a. Dependent Variable: TP

In this section, to address the research objective, Multiple Linear Regression analysis was used to examine the significant factors contributing to the rise of womenpreneurship among B40. The result shows that all factors are significant to womenpreneurship performance. Highest Beta is 0.717 for education in digital skills, which is significant at level 0.000 . It indicates that education in digital skills is the strongest predictor for this study.

\section{CONCLUSION}

In the 21st century, womenpreneurship is not only to fulfill the current trend but can be considered as an engine fuelling innovation, employment generation, and economic growth. Womenpreneurs among B40 are encouraged to move forward to provide more contributions, especially to their own life. Finding of this study shows that inspiring model, education in digital 
International Journal of Entrepreneurship, Business and Creative Economy (IJEBCE), Vol. 1 (1), 25-38

Womenpreneurship Performances in Low Economic Class : An Evidence from Melaka

Iylia Syafiqah Binti Abdul Malik, Vincent Chan, Cheryl Chan

skills, and financial support are significant factors towards contributing to the rise of womenpreneurship among B40. The growth of womenpreneurship can be strengthened by educating digital skills to womenpreneurs. Womenpreneurs among B40 should leverage and master new digital technologies.

An online business platform is vital not only for giant entrepreneurs but all types of businesses regardless of size. Men seem to be more daring to explore the latest applications to grow the business compared to women. Switching method of business operation from offline to online is the best way for womenpreneurs to enlarge their business. There is no denying that in the 21st century, social media such as Facebook, Instagram, TikTok, YouTube, Telegram, and LinkedIn is a powerful tool for businesses to embrace. This platform has improved communication with customers, increased brand awareness, helps to market products or services, and a high chance of growth in sales. Therefore, the benefits of social media can hardly be overstated.

\section{Recommendations \\ Inspiring role model}

Researchers suggest that successful womenpreneurs from the B40 category to conduct a video workshop hosted online using webinar software. A webinar is a combination of the words "web" and "seminar". This is a current trend for entrepreneurs to join a training due to COVID19. In whatever situation, knowledge and skills must remain updated. Apart from giving new input, womenpreneurs indirectly will be impacted by success stories and a high tendency to replicate their mentor.

\section{Financial support}

In order to encourage entrepreneurship, the government provides various platforms such as grants and funds. Initiatives by the government such as TEKUN, SME Corp, Amanah Ikthiar Malaysia (AIM), and Ministry of Women, Family, and Community Development (MWFCD) were introduced to inject positive vibes for Malaysian womenpreneurs to grow their business. However, most of them did not realize these opportunities. Although there are many past reports, academic and non-academic literature gave a positive impression on the number of women business formation, their business remains small and marginal as well as low in growth (Isa, Jaganathan, Ahmdon, \& Ibrahim, 2018). Because of that, researchers suggest increasing awareness and understanding via an online channel such as the WhatsApp application or Facebook page. Information provided through the official website is not effective among B40 womenpreneurs.

\section{Education in digital skills}

Today, we are in the thick of the mobile era. Womenpreneurs must focus on continually seeking knowledge and skills, especially on how to operate digitally to help the business evolve. Collaboration with universities is the best way to update information regarding the latest trends, methods, or technology. It is because universities are the sources of wealth of knowledge and talent. As a woman, getting out of the comfort zone is risky. By collaborating with the university, womenpreneurs will obtain the latest studies and innovations.

Foster women's digital literacy will help to empower womenpreneurship performance. The use of digital platforms is providing women with greater access to markets, improve the position of women in society, more flexible working arrangements, and help to improve many aspects of womenpreneurs' work and life.

\section{ACKNOWLEDGEMENT}

I would like to thank all that, one way or another, contributed to the completion of this study. I have great pleasure in acknowledging my gratitude to my co-authors Mr. Vincent and Ms. Cheryl, for ensuring that the fire keeps burning and being there at times when I required motivation, insightful 
International Journal of Entrepreneurship, Business and Creative Economy (IJEBCE), Vol. 1 (1), 25-38 Womenpreneurship Performances in Low Economic Class : An Evidence from Melaka Iylia Syafiqah Binti Abdul Malik, Vincent Chan, Cheryl Chan

guidance, and also for assisting me in the collation of data for this research. Their support, encouragement, and credible ideas have been great contributors to the completion of the thesis. Thank you so much.

\section{REFERENCES}

Al-Kwifi, O. S., Khoa, T. T., Ongsakul, V., Ahmed, Z. U., Sam, O., \& Khoa, T. (2019). Determinants of female entrepreneurship success across Saudi Arabia. Journal of Transnational Management, 25 (1), 3 -29. https://doi.org/10.1080/15475778.2019.1682769

Asikhia, O.U., Agbonna, A.R., Makinde, G.O. \& Akinlabi, H.B. (2019). Role Model and Attitude towards Entrepreneurship: Beyond the Classroom. Global Scientific Journal, 7 (3), 531 - 539

Aurelio Tommasetti, Pierpaolo Singer, Orlando Troisi and Gennaro Maione (2018). Extended Theory of Planned Behavior (ETPB): Investigating Customers' Perception of Restaurants' Sustainability by Testing a Structural Equation Model. Sustainability 2018, 10, 2580; doi:10.3390/su10072580

Ayogu, Deborah U. \& Agu, Everistus Ogadimma (2015). Assessment of the Contribution of Women Entrepreneur towards Entrepreneurship Development in Nigeria. ISSN: 2347-3215 Volume 3 Number 10 (October-2015) pp. 190-207

Bakar, A. A., \& Ahmad, S. (2016). Determinant factors of women entrepreneurs ' business performance : a conceptual framework. Journal of Global Business and Social Entrepreneurship (GBSE), 1(1), 55-67.

Batool, H. \& Ullah, K. (2017). Successful Antecedents of Women Entrepreneurs: A Case of Underdeveloped Nation. Entrepreneurship Research Journal, 1-11

Berii, D. (2019). The factors affecting women's economic empowerment in micro and small scale enterprise in the case of yeka sub-city. A Thesis Submitted to the School of Graduate Studies of Addis Ababa University In Partial Fulfillment of the Requirement for the Degree of Master of Arts in Regional and Local Development. Addis Ababa, Ethiopia

Boldureanu, G., Ionescu, A.M., Bercu, A.M., Grigoruta, M.V.B. \& Boldureanu, D. (2020). Sustainability $2020,12,1267,1-33$

Bosma N, Hessels J, Schutjens V, et al. (2012). Entrepreneurship and role models. J Econ Psychol 2012; 33: 410-424

Bouzekraoui, H. \& Ferhane, D. (2017). An Exploratory Study of Women's Entrepreneurship in

Morocco. Journal of Entrepreneurship : Research \& Practice 2017, 1-19.

Doris, N. (2016). Factors Influencing the Performance of Female Owned Enterprises: a Case of Businesses in the Central Business District of Nairobi, Kenya. A Project Report Submitted In Partial Fulfillment Of The Requirements For The Award Of Master Of Arts In Project Planning And Management Degree Of The University Of Nairobi, Kenya.

Fatima, H., \& Muneer, A. (2018). Factors Influencing Women Entrepreneurs ' Performance in SMEs.

World Journal of Entrepreneurship, Management and Sustainable Development, 12(2), 82-101.

Filzah Md Isa, Mathivannan Jaganathan, Muhd Afiq Syazwan Ahmdon, Hairunnisa Mohamad Ibrahim (2018). Malaysian Women Entrepreneurs: Some Emerging Issues and Challenges of Entering Global Market. Vol. 8, No. 12, 2018, Pg. 1596 - 1605. http://dx.doi.org/10.6007/IJARBSS/v8-i12/5261 DOI: 10.6007/IJARBSS/v8-i12/5261

Gabriela Boldureanu, Alina Măriuca Ionescu, Ana-Maria Bercu, Maria Viorica Bedrule-Grigorut and 
International Journal of Entrepreneurship, Business and Creative Economy (IJEBCE), Vol. 1 (1), 25-38 Womenpreneurship Performances in Low Economic Class : An Evidence from Melaka Iylia Syafiqah Binti Abdul Malik, Vincent Chan, Cheryl Chan

Daniel Boldureanu (2020). Entrepreneurship Education through Successful Entrepreneurial Models in Higher Education Institutions. Sustainability 2020, 12, 1267; doi:10.3390/su12031267

George, K. (2018). Factors influencing the performance of women entrepreneurs: a case of Iringa municipality. A dissertation submitted to the Faculty of Business and Management Sciences in Fulfillment of the Requirement for the Award the Bachelor of Accounting and Finance with Information Technology. Ruaha Catholic University.

Haxhiu, E. (2015). The Factors Affecting Success and Performance of Women Entrepreneurs in Kosovo. Retrieved from http://www.cek.ef.uni-lj.si/magister/Haxhiu1846-B.pdf

Holienka, M., Jancovicova, Z. \& Kovacicova, Z. (2016). Drivers of women entrepreneur in Visegrad countries: GEM evidence. Procedia - Social ad Behavioral Sciences 220, 124 - 133

Hong, L.M., Sha'ari, MAAH, Zulkiffli, W.F.W., Aziz, R.C. \& Ismail, M. (2020). Determinant Factors that Influence Entrepreneurial Intention Among Students in Malaysia. JMK, 22(1), 80-86

Itani, H Sidani (2011), Female entrepreneurs: Motivations and frustrations. Equality, Diversity and Inclusion International Journal, 30 (5), 409-424

Kampung, M. S., \& Tirimba, O. I. (2014). Factors Affecting the Performance of Small and Micro Enterprises in Limuru Town Market of Kiambu County, Kenya. International Journal of Scientific and Research Publications, 4(12).

Khaleque, A. (2018). Performance of Women Entrepreneurs : Does Access to Finance Really Matter

? Eurasian Journal of Business and Economics, 11(21), 23-48.

Ladge,J., Eddleston, KA \& Sugiyama, K. (2019). Am I an Entrepreneur?How Imposter fears hinder women entrepreneurs' business growth. Business Horizon (2019) 62, 615 - 624

Leszczyński, D. (2016). Exploration of Key Success Factors that Influence Business Performance : The Experiences of Women Micro-entrepreneurs from Mazovia Voivodeship of Poland. International Journal of Management and Economics, 10(51), 63-89. https://doi.org/10.1515/ijme-2016-0020

Mehta, S. (2018). Determinants of Women Entrepreneurs ' Performance in Haryana, India.

International Journal of Current Microbiology and Applied Sciences, 7(10), 193-202.

Mozumdar, L. (2018). Entrepreneurship Against the Tide. Business Performance of Women Entrepreneurs in a constrained environment. A survey in Bangladesh. 1 - 75. DOI $10.18174 / 445484$

Mustapha, Mazlina \& Subramaniam, Punitha (2015). Challenges and success factors of female entrepreneurs : evidence from a developing country. Special Issue for Asia International Conference (AIC)

, 5th - 6th December 2015, UTM

Mutalib \& Arshad (2015). Women and Entrepreneurship: An Overview of Women Entrepreneurship Programs in Malaysia. JGD Special Issue on Social Entrepreneurship,11,1528

Mwania, A. (2015). Factors Influencing the Performance of Women Entrepreneurial Ventures in Kongowea Market, Mombasa County, Kenya. A research project report submitted in partial fulfilment of the requirement for the award of a Master of Arts Degree in Project Planning and Management of the University of Nairobi, Kenya. 
International Journal of Entrepreneurship, Business and Creative Economy (IJEBCE), Vol. 1 (1), 25-38

Womenpreneurship Performances in Low Economic Class : An Evidence from Melaka Iylia Syafiqah Binti Abdul Malik, Vincent Chan, Cheryl Chan

Nneka, AA (2015). Factors that Affect the Performance of Women Entrepreneurs in the Micro Scale Enterprises in Southwestern Nigeria. The Business and Management Review, 6(2), 232 - 239.

Nowinski, W. \& Haddoud, M.Y. (2019). The Role of Inspiring Role Models in Enhancing Entrepreneurial Intention. Journal of Business Research, 96, 183- 193.

Padmavati, D (2002): Training women for entrepreneurship. Social Welfare, 49 (2):15-18.

Saidi, N.A., Rashid, N.A., Zin, N.M., Ramlan, H., Johari, N. \& Mohamad, M.R. (2017). Determinants of Women Entrepreneurs' Performance in SMEs. International Symposium \& Exhibition on Business and Accounting 2017 (ISEBA 2017), 1-6.

Sangolagi, K., \& Alagawadi, M. (2017). Women Entrepreneurs. International Journal of Advancement in Engineering Technology, Management \& Applied Science, 3(1), 216-222.

Satyajit Roy, Priyanka Tripathy and P. K. Tripathy (2017). Assessment of Factors Affecting the Performance of Women Entrepreneurs in MSE in Polosara District of Ganjam, Odisha. British Journal of Economics, Management \& Trade 17(3): 1-11, 2017; Article no. BJEMT.32298 ISSN: 2278-098X

Trang, T.V., Do, QH \& Luong, M.H. (2019). Entrepreneurial human capital, role models and fear of failure and start-up perception of feasibility among adults in Vietnam. International Journal of Engineering Business Management, 11, 1 - 11.

Tuan, N.A., Ha, D.T.H., Thao, V.T.B., Anh, DK. \& Long, N.H. (2019). Factors Affecting Entrepreneurial Intentions Among Youths in Vietnam. Children and Youth Services Review 99, 186 - 193.

Wyrwich M, Stuetzer M, and Sternberg R. (2016) Entrepreneurial role models, fear of failure, and institutional approval of entrepreneurship: a tale of two regions. Small Bus Econ; 46: 467492.

Yusuff, YZMI, Bakar, AA \& Ahmad, S. (2016). Determinants Factors of Women's Entrepreneurs' Business Performance: A Conceptual Framework. Journal of Global Business and Social Entrepreneurship (GBSE), 1 (1), 55 - 67.

Zeb, A. (2018). Determinants of successful women entrepreneurship in Pakistan. Abasyn Journal of Social Sciences, (11), 62-86.

Zeb, Arooj; Jan, Shahid; Ihsan, Anjum; Shah, F. A. A. (2019). Political factors and women's entrepreneurial performance. Pakistan Journal of Commerce and Social Sciences (PJCSS), 13(1), 165-179. Zovko, L., Dulcic, Z. \& Bilic, I. (2020). Determinants of Students' Entrepreneurial Intention: An Empirical Research. Journal of Contemporary Management Issues, 25 (1), 25 - 44. 